Pacific Northwest

National Laboratory

Operated by Battelle for the

U.S. Department of Energy

\title{
Observations on the Oxidation of Mn- Modified Ni-Base Haynes 230 Alloy Under SOFC Exposure Conditions
}

\author{
ZG Yang \\ GG Xia \\ JW Stevenson \\ P Singh
}

July 2005

Prepared for the U.S. Department of Energy under Contract DE-AC05-76RL01830 


\title{
DISCLAIMER
}

This report was prepared as an account of work sponsored by an agency of the United States Government. Neither the United States Government nor any agency thereof, nor Battelle Memorial Institute, nor any of their employees, makes any warranty, express or implied, or assumes any legal liability or responsibility for the accuracy, completeness, or usefulness of any information, apparatus, product, or process disclosed, or represents that its use would not infringe privately owned rights. Reference herein to any specific commercial product, process, or service by trade name, trademark, manufacturer, or otherwise does not necessarily constitute or imply its endorsement, recommendation, or favoring by the United States Government or any agency thereof, or Battelle Memorial Institute. The views and opinions of authors expressed herein do not necessarily state or reflect those of the United States Government or any agency thereof.

\author{
PACIFIC NORTHWEST NATIONAL LABORATORY \\ operated by \\ BATTELLE \\ for the \\ UNITED STATES DEPARTMENT OF ENERGY \\ under Contract DE-AC05-76RL01830
}

Printed in the United States of America
Available to DOE and DOE contractors from the Office of Scientific and Technical Information,
P.O. Box 62, Oak Ridge, TN 37831-0062;
ph: (865) 576-8401
fax: $(865)$ 576-5728
email: reports@adonis.osti.gov

\begin{abstract}
Available to the public from the National Technical Information Service, U.S. Department of Commerce, 5285 Port Royal Rd., Springfield, VA 22161 ph: (800) 553-6847 fax: $(703) 605-6900$ email: orders@ntis.fedworld.gov online ordering: http://www.ntis.gov/ordering.htm
\end{abstract}

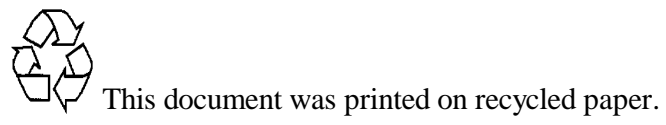




\title{
Observations on the Oxidation of Mn-Modified Ni-Base Haynes 230 Alloy under SOFC Exposure Conditions
}

\author{
ZG Yang JW Stevenson \\ GG Xia P Singh
}

July 2005

Prepared for the U.S. Department of Energy

under Contract DE-AC05-76RL01830

Pacific Northwest National Laboratory

Richland, Washington 99352 


\title{
Observations on the oxidation of Mn-modified Ni-base Haynes 230 alloy under SOFC exposure conditions
}

\begin{abstract}
The commercial Ni-base Haynes 230 alloy (Ni-Cr-Mo-W-Mn) was modified with two increased levels of $\mathrm{Mn}(1$ and $2 \mathrm{wt} \%)$ and evaluated for its oxidation resistance under simulated SOFC interconnect exposure conditions. Oxidation rate, oxide morphology, oxide conductivity and thermal expansion were measured and compared with commercial Haynes 230. It was observed that additions of higher levels of Mn to the bulk alloy facilitated the formation of a bilayered oxide scale that was comprised of an outer $\mathrm{M}_{3} \mathrm{O}_{4}(\mathrm{M}=\mathrm{Mn}, \mathrm{Cr}, \mathrm{Ni})$ spinel-rich layer at the oxide - gas interface over a $\mathrm{Cr}_{2} \mathrm{O}_{3}$-rich sub-layer at the metal - oxide interface. The modified alloys showed higher oxidation rates and the formation of thicker oxide scales compared to the base alloy. The formation of a spinel-rich top layer improved the scale conductivity, especially during the early stages of the oxidation, but the higher scale growth rate resulted in an increase in the area-specific electrical resistance over time. Due to their face-centered cubic crystal structure, both commercial and modified alloys demonstrated a coefficient of thermal expansion that was higher than that of typical anode-supported and electrolyte-supported SOFCs.
\end{abstract}




\section{Introduction}

Over the past several years, the steady reduction in SOFC operating temperatures to the intermediate range of $650 \sim 800^{\circ} \mathrm{C}$ has made it feasible for lanthanum chromite to be supplanted by high temperature oxidation resistant alloys as the stack interconnect materials [1-3]. Compared to doped lanthanum chromite, alloys potentially offer significantly lower raw material and fabrication costs. However, the SOFC operating conditions present significant challenges for alloy-based interconnects.

Among high temperature oxidation resistant alloys, commercially available bodycentered-cubic (BCC) ferritic stainless steels (FSS) are inexpensive and demonstrate good oxidation resistance and the ability to match the coefficient of thermal expansion (CTE) of adjacent cell/stack components. However, FSS may have issues in terms of long-term surface stability and electrical resistance arising from a relatively high scale growth rate, as well as low high temperature mechanical strength. In comparison, the face-centered-cubic (FCC) $\mathrm{Ni}-\mathrm{Cr}$ or $\mathrm{Ni}-\mathrm{Fe}-\mathrm{Cr}$ based alloys (or superalloys in many cases) are generally much stronger and more oxidation resistant (i.e. lower scale growth rate) in the SOFC interconnect operating environment. However, the FCC Ni-based alloys with sufficient $\mathrm{Cr}$ to provide oxidation resistance exhibit a high CTE, typically in the range of $15.0 \sim 20.0 \times 10^{-6} . \mathrm{K}^{-1}$ from room temperature to $800^{\circ} \mathrm{C}$, and are generally more expensive than the FSS. Although Ni-base alloy formulations (Ni-Cr-W-Mo) can be developed for lower CTE, the lower Cr level in the alloy results in insufficient oxidation resistance. Nevertheless, Ni-base alloys may find application as interconnect materials through the use of innovative SOFC stack and seal designs and/or novel interconnect structures. For example, recent proof-of-concept work has confirmed the potential viability of a cladding approach to fabricate a stable composite interconnect structure consisting of FCC Ni-base alloy claddings and a BCC ferritic stainless steel substrate [4]. Thus, identifying or developing a suitable Ni-base alloy can provide another option for SOFC developers in their efforts to design and fabricate stable metallic interconnects.

Recent investigations into FSS for interconnect applications indicated that the presence of $\mathrm{Mn}$ in the ferritic composition helps improve the scale electrical conductivity and minimize the contact resistance of metallic interconnects. One example is Crofer22 APU, a FSS that was developed by Forschungszentrum Julich and commercialized by ThyssenKrupp VDM [5]. The 
addition of $0.5 \% \mathrm{Mn}$ to the $\mathrm{Fe}-22 \% \mathrm{Cr}$ ferritic base composition results in the growth of a unique scale on the alloy surface that is comprised of a $(\mathrm{Mn}, \mathrm{Cr})_{3} \mathrm{O}_{4}$ spinel top layer and $\mathrm{Cr}_{2} \mathrm{O}_{3}$ sub-layer. The spinel top layer (with an electrical conductivity two orders of magnitude higher than that of $\mathrm{Cr}_{2} \mathrm{O}_{3}$ ) results in improved scale conductivity and reduced contact resistance [5,6]. A similar concept of alloy design can also be applied to the FCC Ni-base alloys, which provide more

flexibility of alloying in comparison with the BCC structures. For example, in order to prevent a transformation from a ferritic structure to an austenitic structure, the Mn content of a ferritic structure must remain relatively low. To explore the effect of increased Mn content in FCC Nibase alloys, Haynes 230, a superalloy with superior oxidation resistance and high temperature mechanical strength, was selected as a baseline material to be modified by increasing the $\mathrm{Mn}$ content. The modified compositions were then systematically evaluated for:

i) scale growth and structure,

ii) oxidation behavior in air, hydrogen, and air/hydrogen dual atmospheres,

iii) scale electrical conductivity,

iv) thermal expansion.

Details of the alloy fabrication and the results of the aforementioned evaluations are reported and discussed in this report.

\section{Alloy Compositions and Fabrication}

Two alloys based on Haynes 230, but containing 1\% and 2\% Mn (designated M1 and M2, respectively), were fabricated by Haynes International, Inc. in Kokomo, Indiana. For each alloy, as schematically shown in Figure 1,50 lbs of elemental constituents were first melted in a vacuum induction furnace and then refined in an electroslag remelting furnace before being cast into an ingot. The alloy ingot was subsequently forged into a plate that was then hot and coldrolled and annealed repeatedly to a thickness of 40 mils $(1.0 \mathrm{~mm})$. The chemical compositions of the M1 and M2 as determined in the final product are given in Table I along with that of commercial Haynes230. It should be noted that cobalt was not intentionally added as an alloying element in the commercial Haynes230, but was introduced during commercial melting. In contrast, the new alloys were prepared with elemental metals which contained no cobalt. 


\section{Evaluation of Materials Properties}

\section{Scale Growth and Structure}

To evaluate their oxidation resistance and analyze their scale structure, the alloys M1 and M2 were oxidized in moist air (air w/ $\sim 3 \% \mathrm{H}_{2} \mathrm{O}$ ) at $800^{\circ} \mathrm{C}$ for up to 1,000 hours. The oxidized samples were analyzed by XRD, and then cross-sectioned and analyzed by SEM. Figure 2 shows the XRD results on the M1 and M2 samples after oxidation in air for 100, 500, and 1,000 hours, indicating that the scales grown on the alloys were comprised of $\mathrm{Cr}_{2} \mathrm{O}_{3}, \mathrm{M}_{3} \mathrm{O}_{4}(\mathrm{M}=\mathrm{Mn}, \mathrm{Ni}$, $\mathrm{Cr}$ ), and occasionally a small amount of $\mathrm{NiO}$. Due to penetration of X-rays through the scales, diffraction peaks of the FCC metal substrate and $\gamma$ ' precipitates are also visible in the patterns. Detailed examination of the XRD patterns further revealed that the M2 scale contained a higher fraction of spinel phase than the scale grown on M1; for both alloys the spinel content in the scale increased with increased time of oxidation. SEM/EDS point analyses on the cross-sections, shown in Figure 3, indicated Mn enrichment in the top of the scale, which was likely comprised of a Mn-containing spinel-rich top layer and a chromia or chromia-rich sub-layer. The scale composition was further confirmed by EDS linear analysis on the cross-section as shown in Figure 8(a). Similar to Crofer22 APU [5,6], it appears that the increased Mn content enhanced the spinel formation and growth of the spinel top layer, leading to the growth of a scale with a bilayer structure.

To evaluate their oxidation resistance, the scale thickness of the newly developed alloys was measured as a function of time via the SEM cross-section analyses. Figure 4 shows the cross-sections of $\mathrm{M} 1$ and $\mathrm{M} 2$ after 300 hours of oxidation at $800^{\circ} \mathrm{C}$ in moist air. For comparison, the cross-sections of Haynes 230 and Crofer22 APU after oxidation under similar conditions are also included in the figure. It can be seen that the scale thickness increases in the order of Haynes230, M1 and M2, indicating that increasing Mn content increased the scale growth rate and decreased the oxidation resistance. However, these alloys were still more oxidation resistant than Crofer22 APU. This trend became more obvious when the alloys were oxidized under more realistic SOFC interconnect operating conditions. Figure 5 shows the airside SEM cross-sections of the modified alloys after oxidation at $800^{\circ} \mathrm{C}$ for 300 hours under dual atmosphere exposure conditions, i.e. with moist air $\left(\operatorname{air}+3 \% \mathrm{H}_{2} \mathrm{O}\right)$ on one side (air side) and moist hydrogen $\left(\mathrm{H}_{2}+3 \% \mathrm{H}_{2} \mathrm{O}\right)$ on the other (hydrogen side). For comparison, cross-sections of Haynes 230 and Crofer 22 APU tested under similar conditions are also included. After 300 hours at $800^{\circ} \mathrm{C}$, the 
scale on Haynes230 grew to a thickness less than 0.5 micron, while the scales on M1 and M2 grew to a thickness of $\sim 1.5$ and $\sim 2.0$ microns, respectively. Overall, these Ni-based alloys demonstrated better oxidation resistance than Crofer22 APU, which exhibited anomalous oxidation behavior, leading to a thick scale and localized attack involving formation of iron oxide nodules [8].

\section{Oxidation Behavior in Air, Hydrogen, and Dual Atmospheres}

The dual atmosphere oxidation tests mentioned above were carried out in a specifically designed apparatus in which an alloy coupon sample was brazed to the end of a stainless steel tube. During the test, the sample was exposed simultaneously to moist air outside the tube and moist hydrogen inside the tube. For purposes of comparison, another alloy coupon was placed in the tube and exposed to moist hydrogen only, while another coupon was placed beneath the tube and exposed to moist air only during the test [7-9]. After completion of the test, the samples were subjected to surface XRD and cross-section SEM/EDS analyses.

Figure 6 shows XRD patterns from the scales grown on the M1 samples during the 300 hours oxidation under different exposure conditions. It was found that the scales grown on the sample exposed to moist hydrogen only, and that on the hydrogen-side of the dual exposure sample, were mainly comprised of $\mathrm{M}_{3} \mathrm{O}_{4}(\mathrm{M}=\mathrm{Mn}, \mathrm{Ni}, \mathrm{Cr})$ spinel and $\mathrm{Cr}_{2} \mathrm{O}_{3}$. $\mathrm{NiO}$ was not observed, which is not surprising, since $\mathrm{NiO}$ is not stable in a moist hydrogen environment. In comparison, in addition to the spinel and chromia phases, $\mathrm{NiO}$ was observed in the scale grown on the sample that was exposed to moist air only, and also appeared to be present, but at a lower concentration, in the scale grown on the airside of the dual exposure sample. Thus the dual atmosphere exposure apparently inhibited $\mathrm{NiO}$ formation in the airside scale, presumably due to hydrogen diffusion through the alloy from the fuel side to the air side. It is possible that a hydrogen flux from the fuel side to the air side changed the local environment (to a less oxidizing state) at the air side, inhibiting the formation and growth of $\mathrm{NiO}$, though the details regarding the interaction between hydrogen and the oxide scale are not clearly understood at this time. Further SEM/EDS analyses on the cross-sections (see Figure 7 (a) and (b), and Figure 8 (a) and (b)) revealed a difference in microstructure between the scale on the sample in air only and the scale on the air side of the dual exposure sample. Under the dual atmosphere exposure, the scale grown on the air side of the dual exposure sample appeared to be thinner, possibly due to the inhibited growth 
of $\mathrm{NiO}$ in the scale at the airside. Furthermore, no voids were observed along the boundary between the metal substrate and the airside scale, while voids were found at the boundary between the metal substrate and the scale grown in air only (Figure 7(a)). Despite these structural differences, EDS analyses indicated both scales were comprised of a spinel-rich top layer and a chromia-rich sub-layer.

In comparison, no substantial difference was observed between the scale grown in hydrogen only and the one grown on the hydrogen side of the dual atmosphere sample, as shown in Figure 7 (c) and (d), respectively.

The anomalous oxidation behavior was also observed for M2 when tested under the dual exposure conditions. The oxidation behavior appeared to be very similar to that of M1; figure 9 shows the XRD patterns from the M2 samples.

Overall it can be concluded that the air side oxidation behavior of the modified Ni-Cr-W-Mn base alloys under dual atmosphere exposure differs from that of the alloys when exposed to air only. The difference in behavior can be attributed to hydrogen transport through the alloy from the fuel side to the air side and its subsequent presence at the air side, although the specific mechanisms which hinder $\mathrm{NiO}$ formation and prevent void formation at the scale/alloy interface are not presently understood.

\section{Scale Electrical Conductivity}

To function well as a bi-polar plate, the interconnect must offer a low resistance electrical path in order to minimize resistive losses within SOFC stacks. For oxidation resistant alloys, the electrical resistance is the sum of two parts, bulk resistance and scale resistance. For high temperature applications such as the SOFC interconnect, the electrical resistance of the scale usually dominates the electrical behavior of the oxidation resistant alloys. In this work, the electrical conductivity was measured using a four-point technique with Pt paste as the electrical contact material. To form a continuous, thin oxide scale for prevention of direct contact between the Pt paste and the metal matrix, all coupons were pre-oxidized at $800^{\circ} \mathrm{C}$ for 100 hours before the conductivity tests. Details about the scale conductivity measurement can be found in a recent publication [6]. The measured electrical conductivity of M1 and M2 as a function of time at $800^{\circ} \mathrm{C}$ in air is shown in Figure 10. For comparison, results from 500 hour tests on Haynes 230 
under the same test conditions are also included. It can be seen that M1 and M2 exhibited low initial ASR, but a higher rate of increase over time than Haynes230. This behavior is consistent with their lower oxidation resistance and different scale compositions. M2, with the highest Mn content, demonstrated a higher scale growth rate and thus a higher rate of increase of ASR than M1. The differences in ASR in the early stages of the tests may be due to the faster formation of a continuous spinel top layer on M1 and M2 compared to the Haynes230, which contained less than $0.5 \% \mathrm{Mn}$.

Overall the modified alloys demonstrated a scale conductivity that was higher than that of many commercial compositions including traditional ferritic stainless steels, and comparable to that of the recently developed stainless steel Crofer22 APU.

\section{Thermal Expansion}

The thermal expansion mismatch of adjacent components in the SOFC stack gives rise to a thermal stress $\sigma$, which can be estimated by $\sigma=E . \Delta \alpha . \Delta T$, where $\Delta \alpha$ is the difference in coefficient of thermal expansion (CTE) between components such as the interconnects and the cells, $\Delta \mathrm{T}$ is the change in temperature that the stack experiences, and $\mathrm{E}$ is the elastic modulus of the interconnects. To minimize the thermal stress and thus improve the stack's thermomechanical stability, it is desirable for the interconnect to have a CTE matching that of the cell (which is typically in the range of $10.5 \sim 12.5 \times 10^{-6} \cdot \mathrm{K}^{-1}$, depending on whether the cell is electrolyte- or electrode-supported) and other adjacent components such as seals.

The linear CTE of the modified Ni-Cr-W-Mn base alloys was determined with a commercial dilatometer. The thermal expansion of M1 and M2 as a function of temperature is shown in Figure 11 along with that of Haynes230. As expected, given the similarity of their compositions, the three alloys had similar thermal expansion behavior. With a FCC matrix, the newly developed alloys and Haynes230 demonstrated a higher CTE than the BCC ferritic stainless steels, which typically have a CTE of $12.0 \sim 13.0 \times 10^{-6} \mathrm{~K}^{-1}$. M2, with $2 \% \mathrm{Mn}$, exhibited a slightly higher average CTE $\left(14.9 \times 10^{-6} \mathrm{~K}^{-1}\right.$ from $20^{\circ} \mathrm{C}$ to $\left.800^{\circ} \mathrm{C}\right)$ than $\mathrm{M} 1\left(14.3 \times 10^{-6} \mathrm{~K}^{-1}\right)$.

As stated in the introduction, the higher CTE of the Ni-Cr-W-Mn base alloys can create challenges for rigidly sealed SOFC stacks. CTE mismatch issues can potentially be solved by modification of stack or seal design and/or the development of novel interconnect structures, 
such as clad structures. As proof-of-concept work, the newly developed alloys were fabricated as thin cladding layers on a FSS substrate (AL453) by EMS, Inc. As shown in Figure 12, wellbonded, uniform interfaces were formed between the Ni-Cr-W-Mn base alloys and AL453. As demonstrated by previous work on clad Haynes230\|AL453 [4], the clad materials made from the newly developed Ni-Cr-W-Mn base alloys and AL453 would be expected to have a CTE that is close to that of AL453. In addition to helping resolve the CTE issue, clad structures can also help offset the high cost of Ni-base alloys.

\section{Summary}

Two Ni-Cr-W-Mn base alloys based on Haynes 230, but with higher Mn content, were prepared and subsequently evaluated against criteria relevant to the SOFC interconnect application, including oxidation resistance, oxidation behavior under SOFC interconnect operating conditions, scale electrical conductivity, and thermal expansion.

Similar to Crofer22 APU, additions of Mn into the Ni-Cr-W base led to the formation of a scale that was comprised of a $\mathrm{M}_{3} \mathrm{O}_{4}(\mathrm{M}=\mathrm{Mn}, \mathrm{Cr}, \mathrm{Ni}, \ldots)$ spinel-rich top layer and $\mathrm{Cr}_{2} \mathrm{O}_{3}$-rich sub-layer. Increasing the Mn content from 1 to $2 \%$ appeared to enhance formation of the spinel phase and facilitate growth of a continuous spinel top layer during the early stages of high temperature exposure. Under simultaneous dual atmosphere exposure, the Ni-Cr-W-Mn base alloys exhibited a different oxidation behavior at the air side of dual exposure samples in comparison with that of samples exposed to air only, leading to formation of a more protective scale at the air side. Overall, the newly developed Ni-Cr-W-Mn base alloys demonstrated good oxidation resistance under SOFC interconnect operating conditions, though the Mn additions increased the scale growth rate and therefore resulted in reduced oxidation resistance compared to the baseline Haynes 230.

The formation of a spinel-rich top layer improved the scale conductivity, especially in the early stages of oxidation. However, the increased Mn content led to a higher scale growth rate and thus a higher rate of increase in ASR. With a FCC matrix, the Ni-Cr-W-Mn base alloys demonstrated a CTE that was higher than that of anode-supported or electrolyte-supported PENs. The high CTE as well as high cost of Ni-based alloys can potentially be offset by integrating Ni- 
base alloys as claddings into a composite interconnect structure with a ferritic stainless steel substrate.

\section{Acknowledgements}

The authors would like to thank Nat Saenz, Shelly Carlson, and Jim Coleman for their assistance in metallographic and SEM sample preparation and analysis. The clad structures were prepared by Engineered Materials Solutions, Inc. The work summarized in this paper was funded as part of the Solid-State Energy Conversion Alliance (SECA) Core Technology Program by the U.S. Department of Energy's National Energy Technology Laboratory (NETL). The authors would like to acknowledge helpful discussions with Wayne Surdoval, Lane Wilson, Don Collins, and Travis Schulz. PNNL is operated by Battelle Memorial Institute for the U.S. Department of Energy under Contract DE-AC06-76RLO 1830.

\section{References}

1. 1. B.C.H. Steele, Nature, 414, 345 (2001).

2. W.J. Quaddakkers, J. Piron-Abellan, V. Shemet, and L. Singheiser, Materials of High Temperature, 20, 115 (2003).

3. Z. Yang, K.S. Weil, D.M. Paxton, and J.W. Stevenson, J. Electrochem. Soc., 150, A1188 (2003).

4. L. Chen, Z. Yang, B. Jha, G. Xia, and J.W. Stevenson, J. Power Sources, 142, 2005, in press.

5. W.J. Quadakkers, V. Shemet, and L. Singheiser, US Paten No. 2003059335 (2003).

6. Z. Yang, J.S. Hardy, M.S. Walker, G. Xia, S.P. Simner, and J.W. Stevenson, J. Electrochem. Soc., 151, A1825 (2004).

7. Z. Yang, M.S. Walker, P. Singh, and J.W. Stevenson, Electrochem. \& Solid State Lett., 6, B35 (2003).

8. Z. Yang, M.S. Walker, P. Singh, J.W. Stevenson, and T. Norby, J. Electrochem. Soc., 151, B669 (2004).

9. Z. Yang, G. Xia, P. Singh, and J.W. Stevenson, Solid State Ionics, in press. 
Table I. Chemical compositions of commercial Haynes 230 and the newly developed Ni-Cr-W-Mn base alloys.

\begin{tabular}{|c|c|c|c|}
\hline Heat No. & 83057804 & & \\
\hline $\begin{array}{l}\text { Chemical } \\
\text { composition }\end{array}$ & Haynes $230 *$ & $\begin{array}{c}1 \% \mathrm{Mn} \\
\text { EN1304-4-812 } \\
\text { M1 }\end{array}$ & $\begin{array}{c}2 \% \mathrm{Mn} \\
\text { EN1404-4-813 } \\
\text { M2 }\end{array}$ \\
\hline $\mathrm{Al}$ & 0.34 & 0.31 & 0.38 \\
\hline B & 0.002 & 0.005 & 0.006 \\
\hline $\mathrm{C}$ & 0.100 & 0.111 & 0.095 \\
\hline $\mathrm{Co}$ & $<5.0$ & $<0.01$ & $<0.01$ \\
\hline $\mathrm{Cr}$ & 22.45 & 20.96 & 20.73 \\
\hline $\mathrm{Cu}$ & 0.05 & 0.03 & 0.04 \\
\hline $\mathrm{Fe}$ & 1.54 & $<0.01$ & $<0.01$ \\
\hline $\mathrm{La}$ & 0.017 & $<0.005$ & $<0.005$ \\
\hline $\mathrm{Mn}$ & 0.52 & 1.08 & 2.06 \\
\hline Mo & 1.42 & 2.02 & 1.95 \\
\hline $\mathrm{Ni}$ & $\mathrm{Bal}$ & 60.67 & 59.49 \\
\hline $\mathrm{P}$ & 0.005 & 0.005 & 0.006 \\
\hline $\mathrm{S}$ & $<0.002$ & 0.003 & 0.002 \\
\hline $\mathrm{Si}$ & 0.38 & 0.42 & 0.42 \\
\hline $\mathrm{Ta}$ & $<0.100$ & 0.06 & 0.06 \\
\hline $\mathrm{Ti}$ & $<0.01$ & $<0.010$ & $<0.010$ \\
\hline W & 14.23 & 13.62 & 14.34 \\
\hline
\end{tabular}

* Trade mark of Haynes International Inc. 


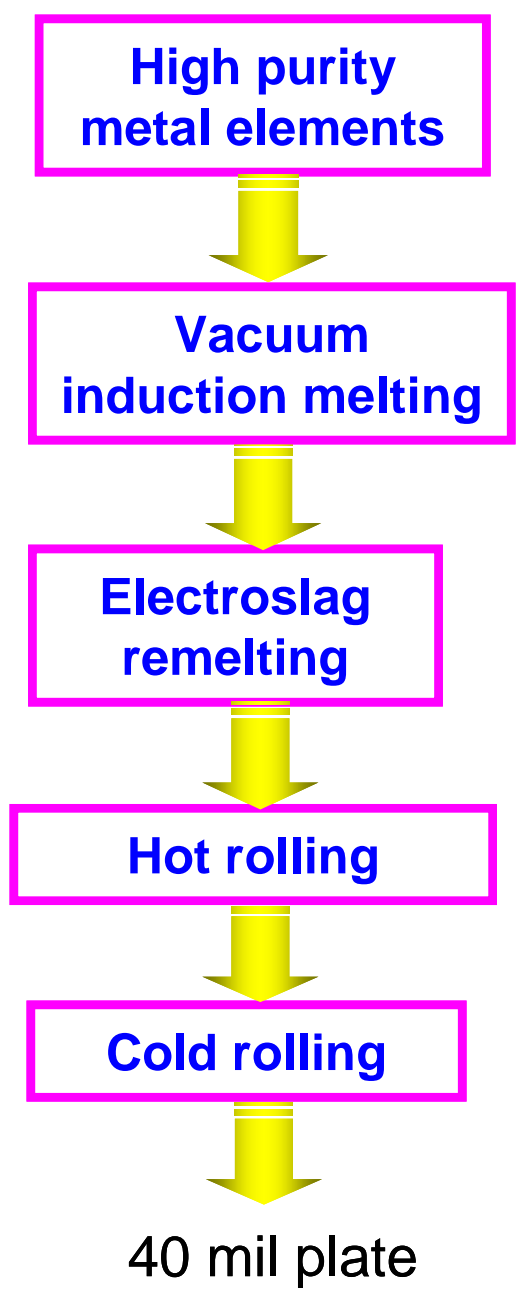

Figure 1. Schematic of preparation of Ni-Cr-W-Mo-Mn alloys. 


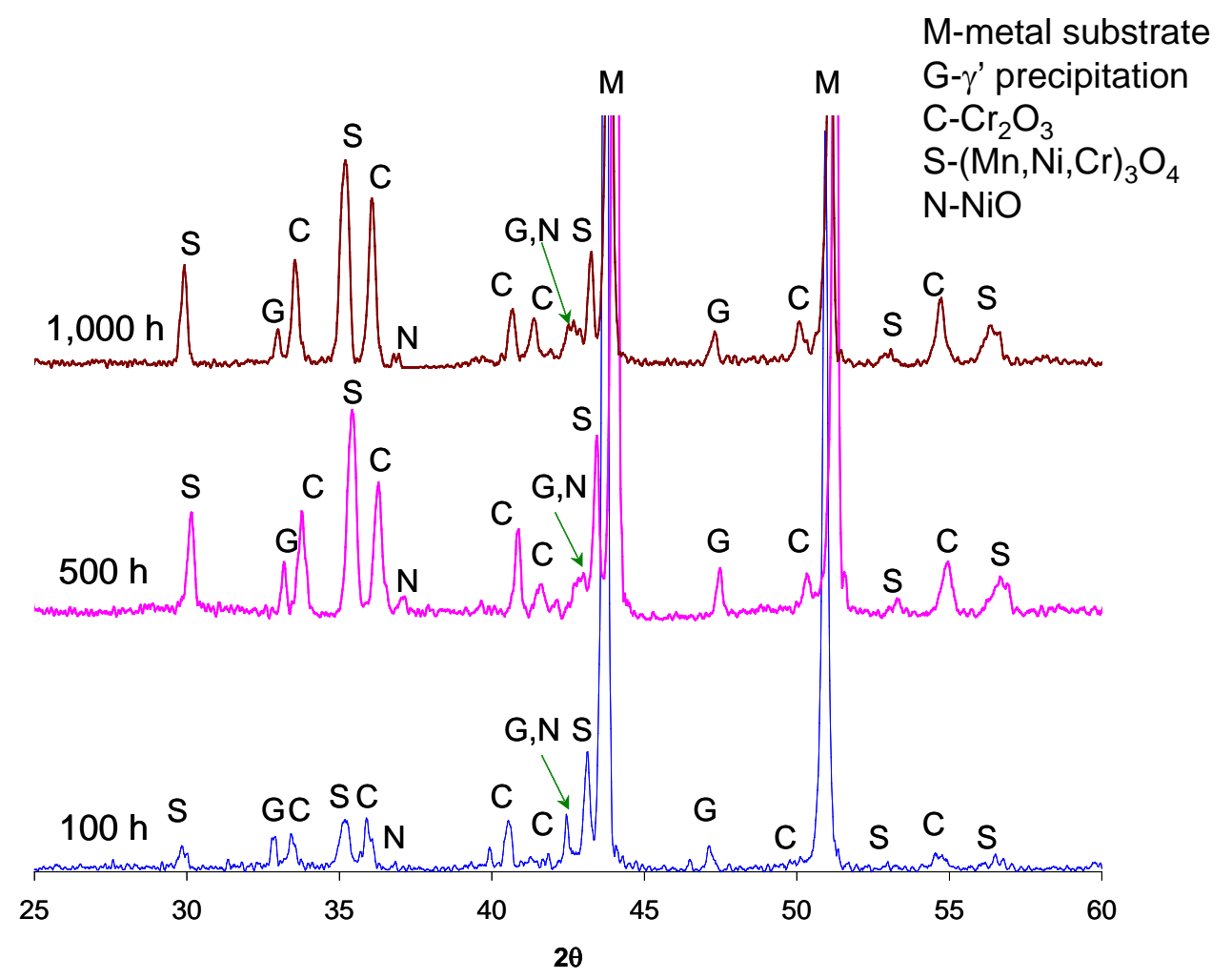

(a)

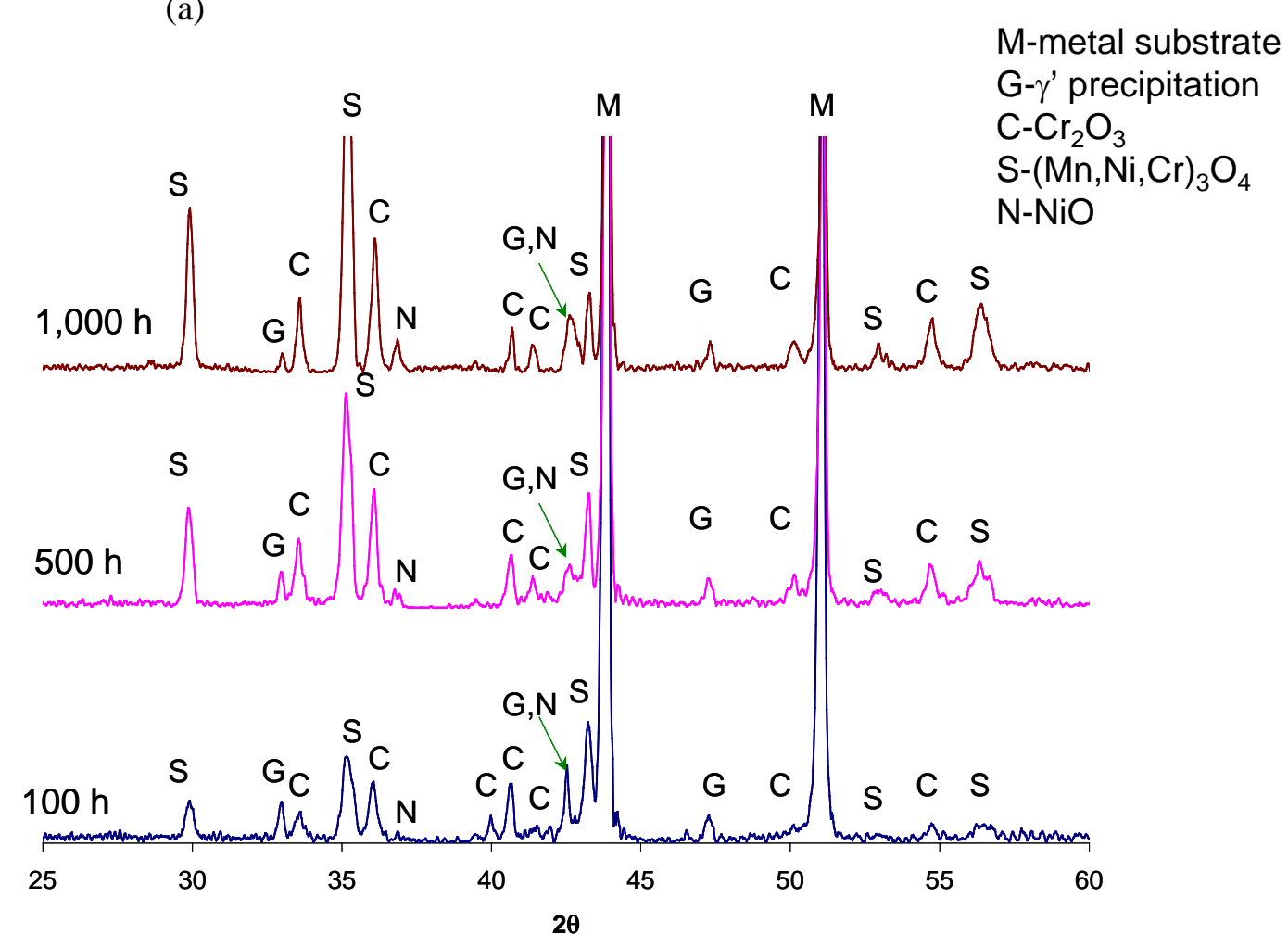

(b)

Figure 2. XRD patterns of scales grown on the newly developed Ni-Cr-W-Mn base alloys during isothermal oxidation in air at $800^{\circ} \mathrm{C}$ for 300,500 , and 1000 hours: (a) M1 (1\% Mn); (b) M2 (2\% $\mathrm{Mn})$. 


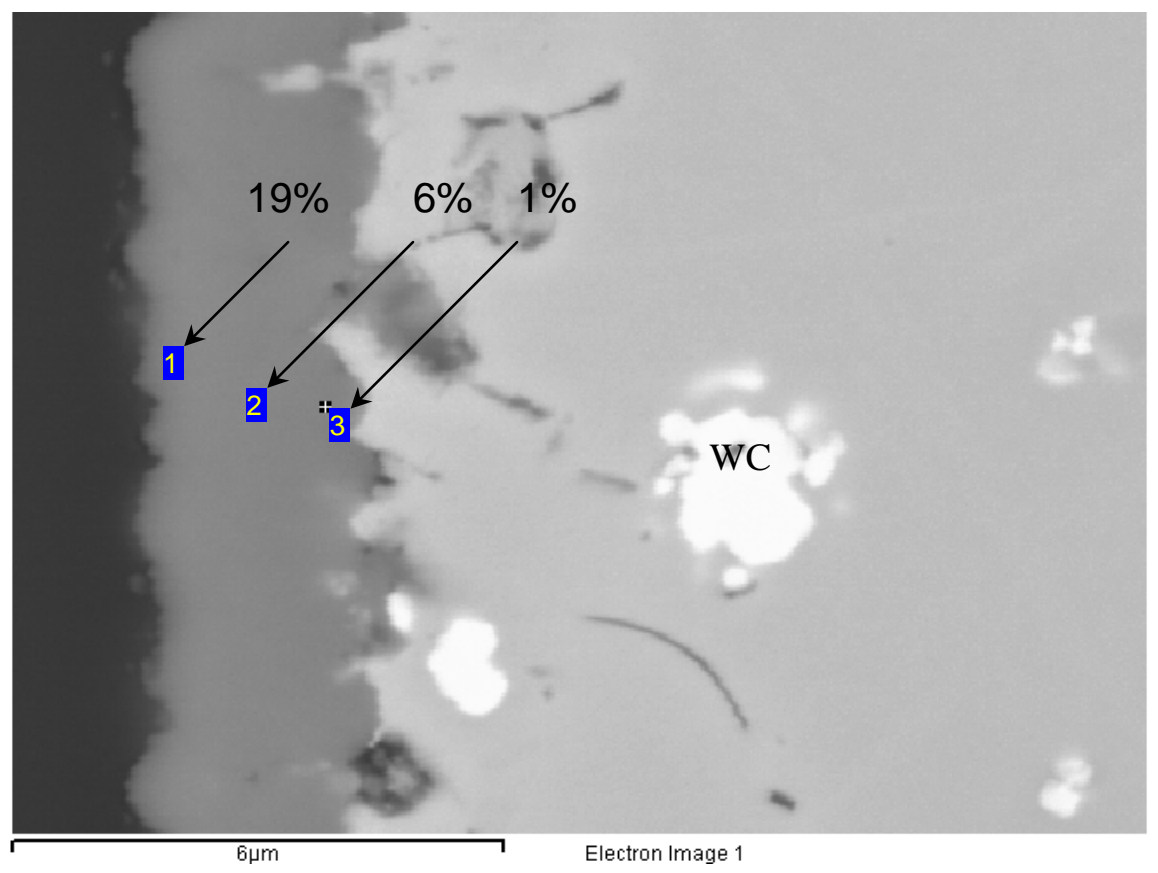

Figure 3. SEM cross-section of the scale grown on the M2 alloy after oxidation at $800^{\circ} \mathrm{C}$ in moist air for 1,000 hours, including Mn\% from EDS point analyses at different locations. 
$\mathrm{M} 1-1 \% \mathrm{Mn}$

(a)

$\mathrm{M} 2-2 \% \mathrm{Mn}$

(c)

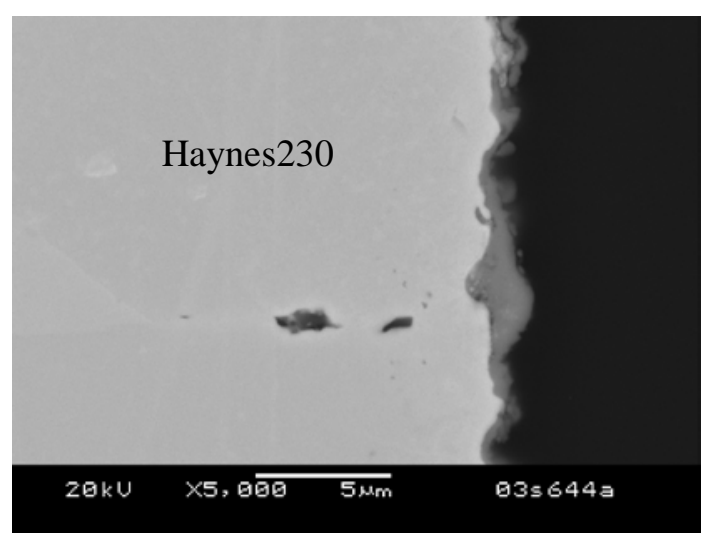

(b)

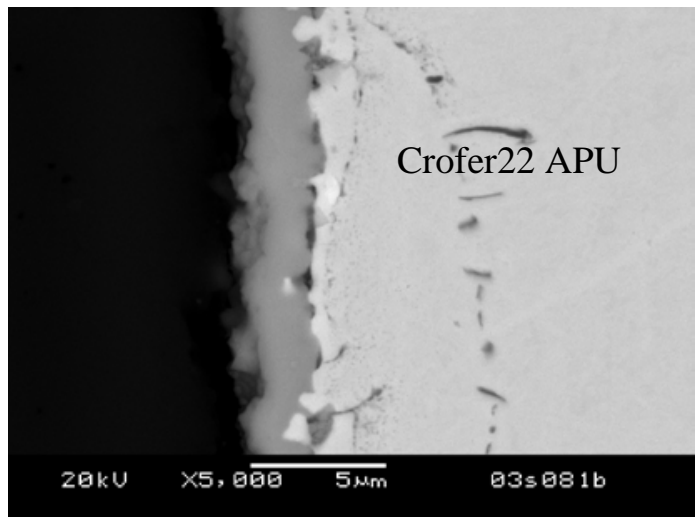

(d)

Figure 4. SEM cross-sections of the newly developed Ni-Cr-W-Mn base alloys (M1, 1\% Mn; $\mathrm{M} 2,2 \% \mathrm{Mn}$ ) in comparison with those from Haynes230 and Crofer22 APU after oxidation in moist air (air $+3 \% \mathrm{H}_{2} \mathrm{O}$ ) at $800^{\circ} \mathrm{C}$ for 300 hours: (a) M1, (b) Haynes230, (c) M2, (d) Crofer22 APU. 


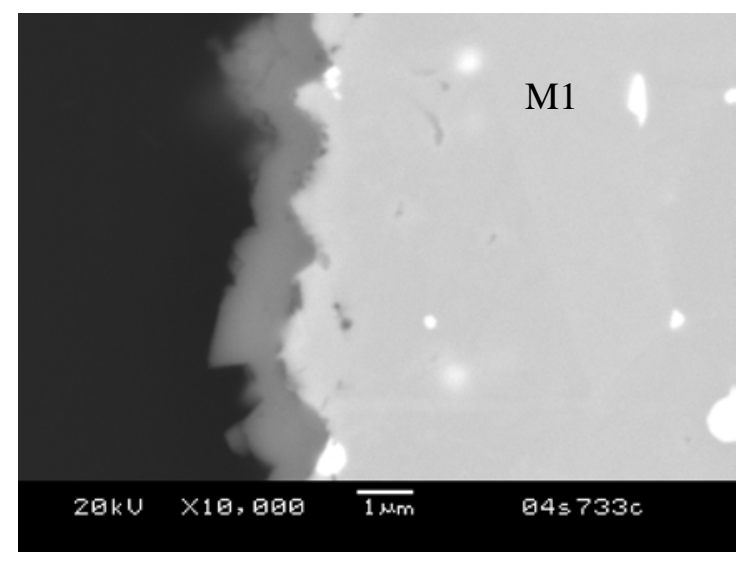

(a)

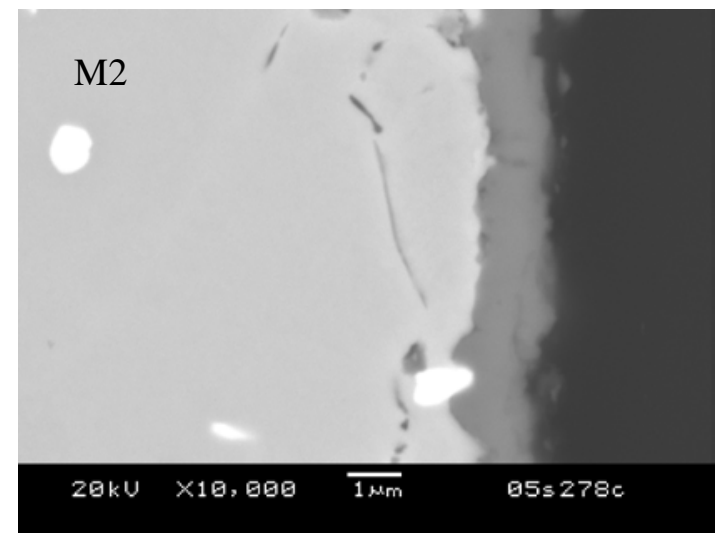

(c)

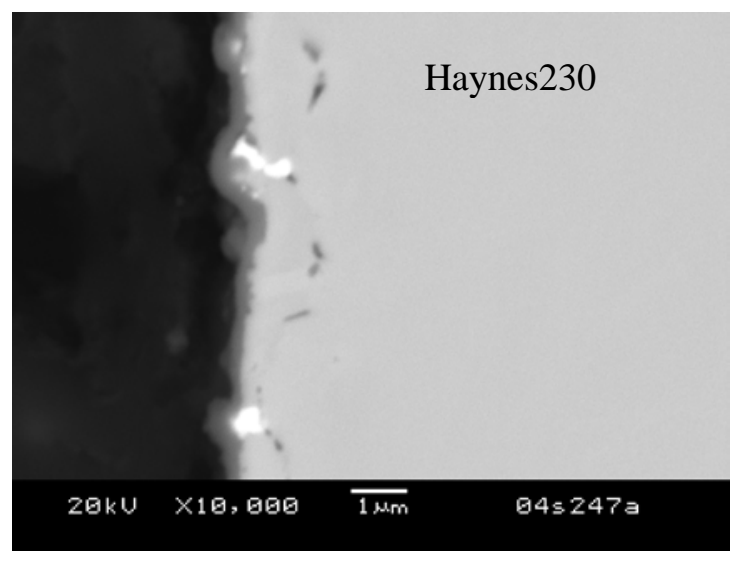

(b)

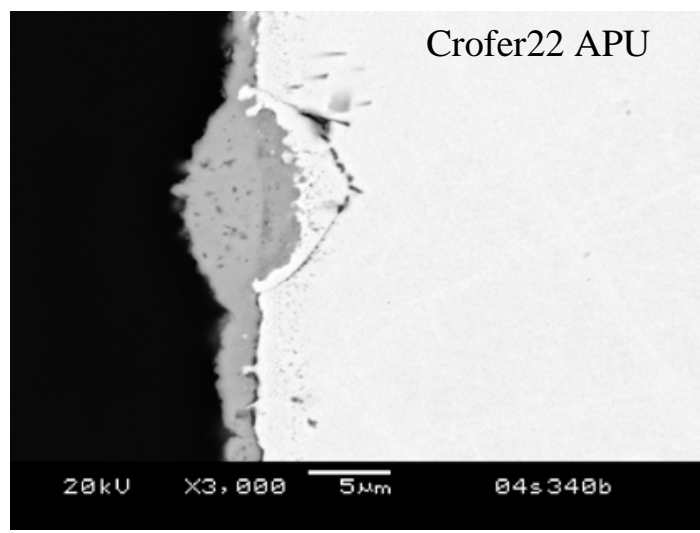

(d)

Figure 5. SEM cross-sections at airside of the newly developed Ni-Cr-W-Mn base alloys (M1, $1 \% \mathrm{Mn} ; \mathrm{M} 2,2 \% \mathrm{Mn}$ ) after oxidation at $800^{\circ} \mathrm{C}$ for 300 hours under dual exposures, i.e. with moist air $\left(\right.$ air $\left.+3 \% \mathrm{H}_{2} \mathrm{O}\right)$ at one side (airside) and moist hydrogen $\left(\mathrm{H}_{2}+3 \% \mathrm{H}_{2} \mathrm{O}\right)$ at the other (hydrogen side), in comparison with those of Haynes230 and Crofer22 APU under the similar conditions: (a) M1, (b) Haynes230, (c) M2, (d) Crofer22 APU. 


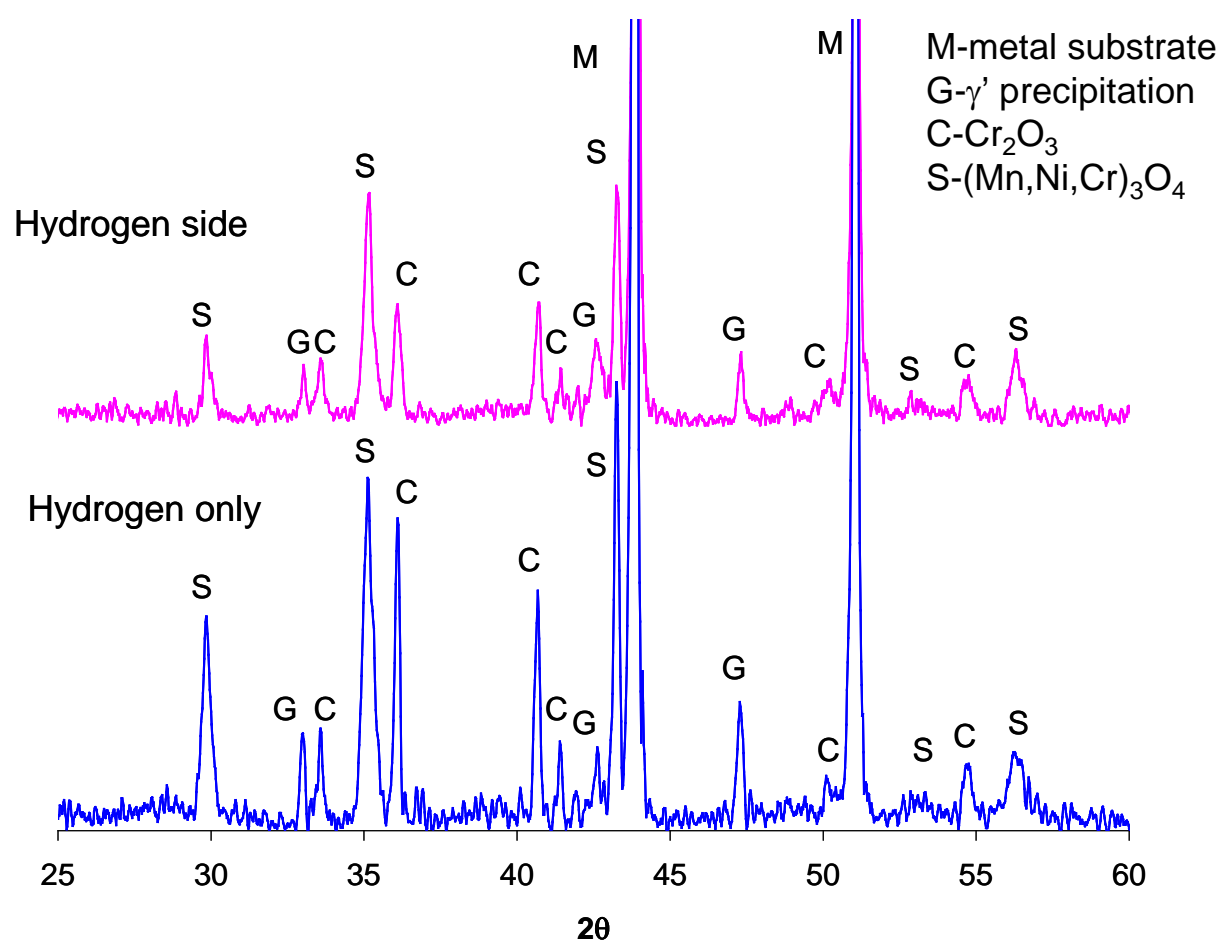

(a)

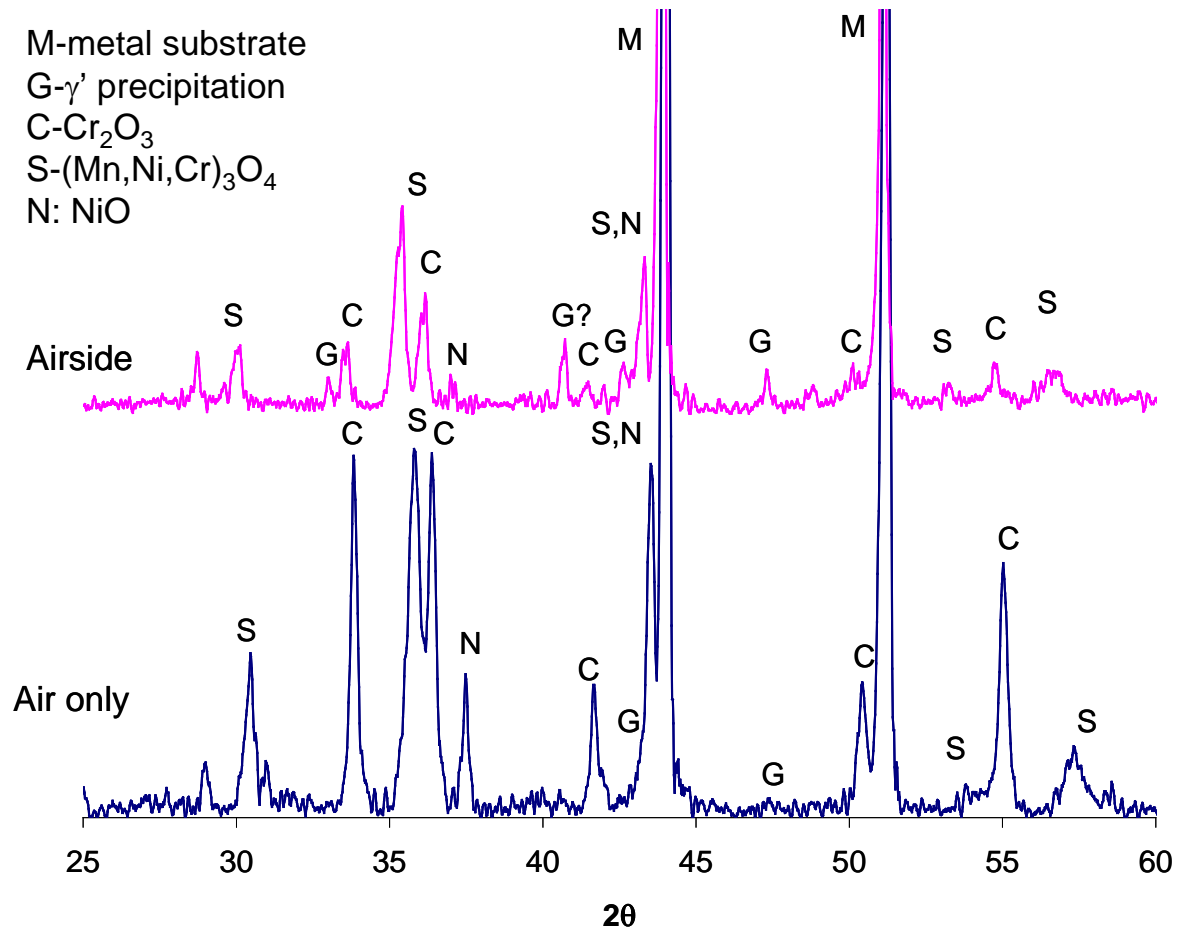

(b)

Figure 6. XRD patterns of scales grown on M1 during oxidation at $800^{\circ} \mathrm{C}$ for 300 hours: (a) at the hydrogen side of the sample that was exposed to air at the other side in comparison with that of the sample exposed to hydrogen only; (b) at the airside of the dual exposure sample in comparison with that of the sample exposed to air only. 


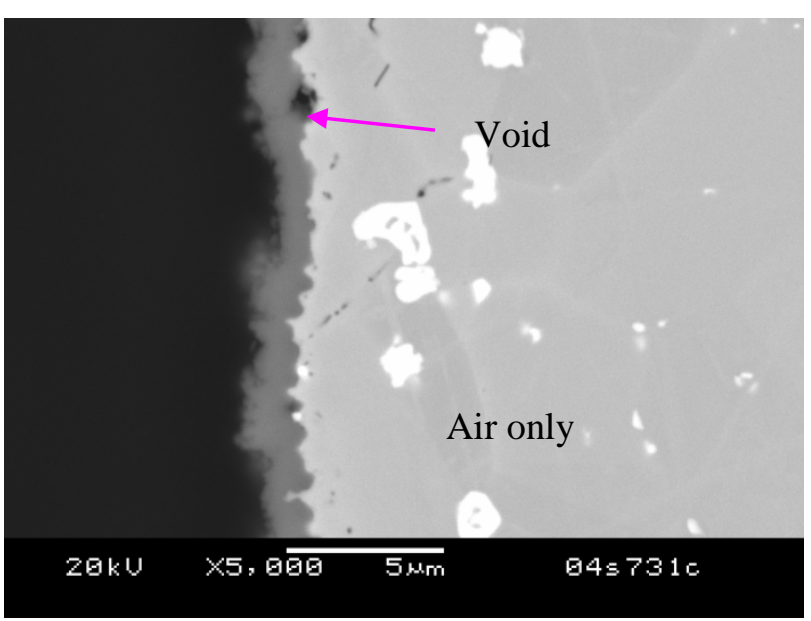

(a)

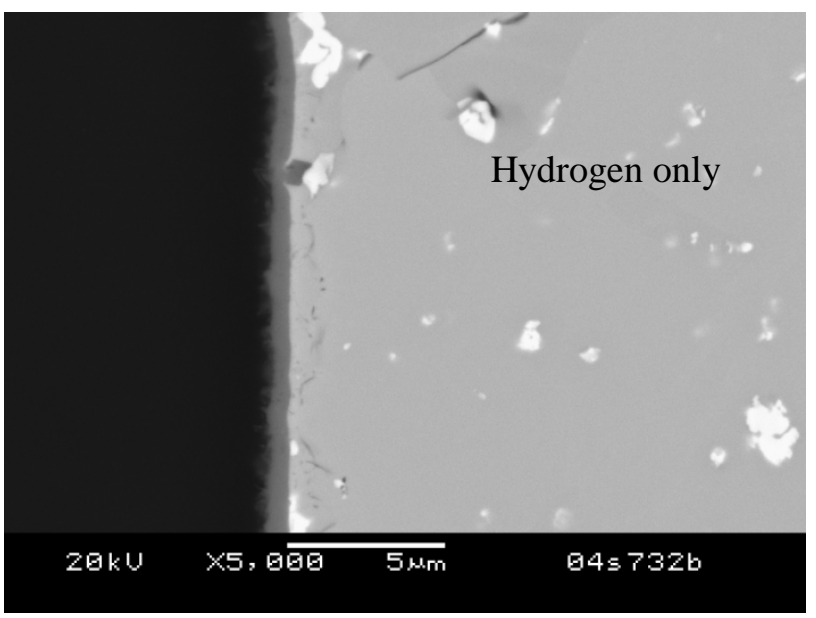

(c)

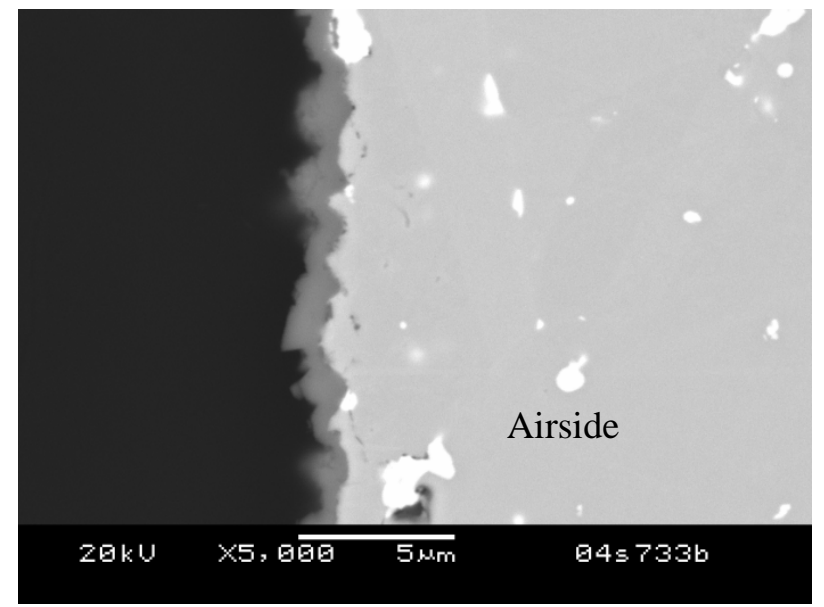

(b)

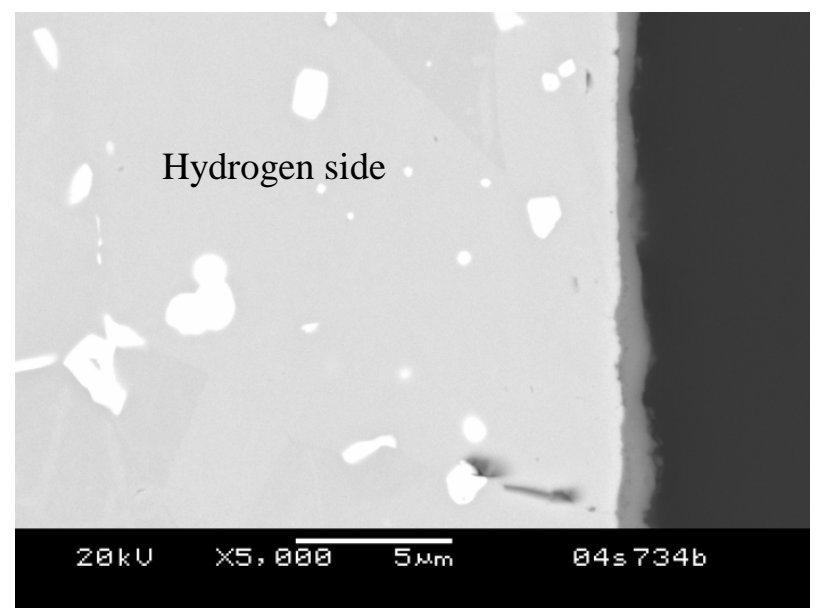

(d)

Figure 7. SEM cross-sections of M1 after oxidation for 300 hours at $800^{\circ} \mathrm{C}$ under different exposure conditions: (a) exposed to air only, (b) the airside of the dual exposure sample, (c) exposed to hydrogen only, and (d) the hydrogen side of the dual exposure sample. 


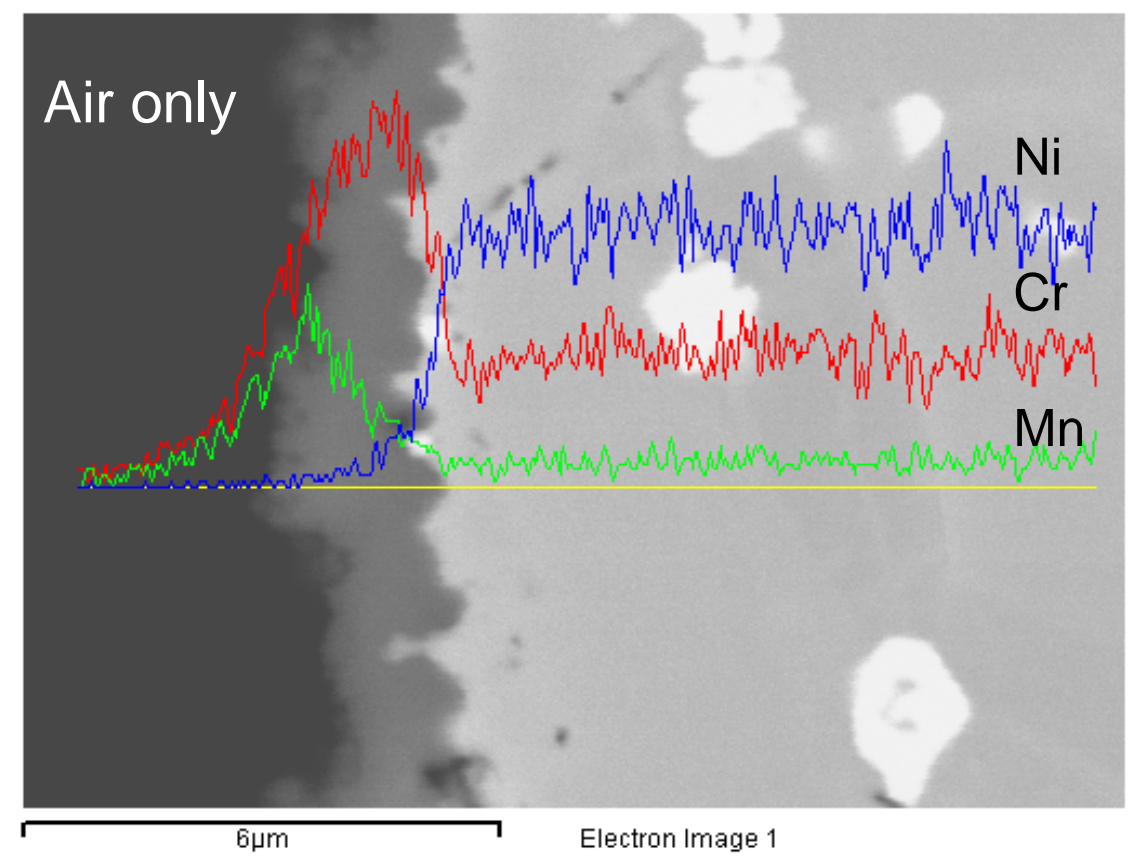

(a)

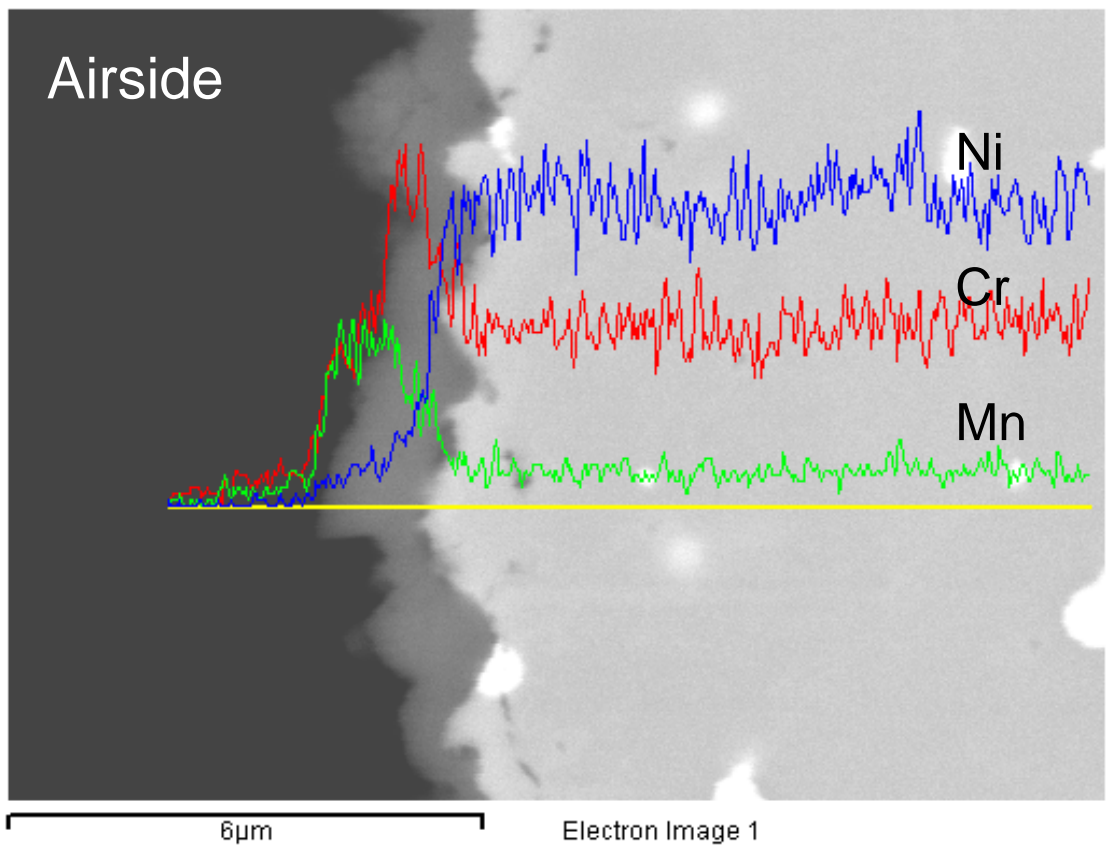

(b)

Figure 8. SEM EDS linear scan across the cross-sections of (a) the sample that was exposed to air only and (b) the airside of the sample exposed to the dual atmospheres. 


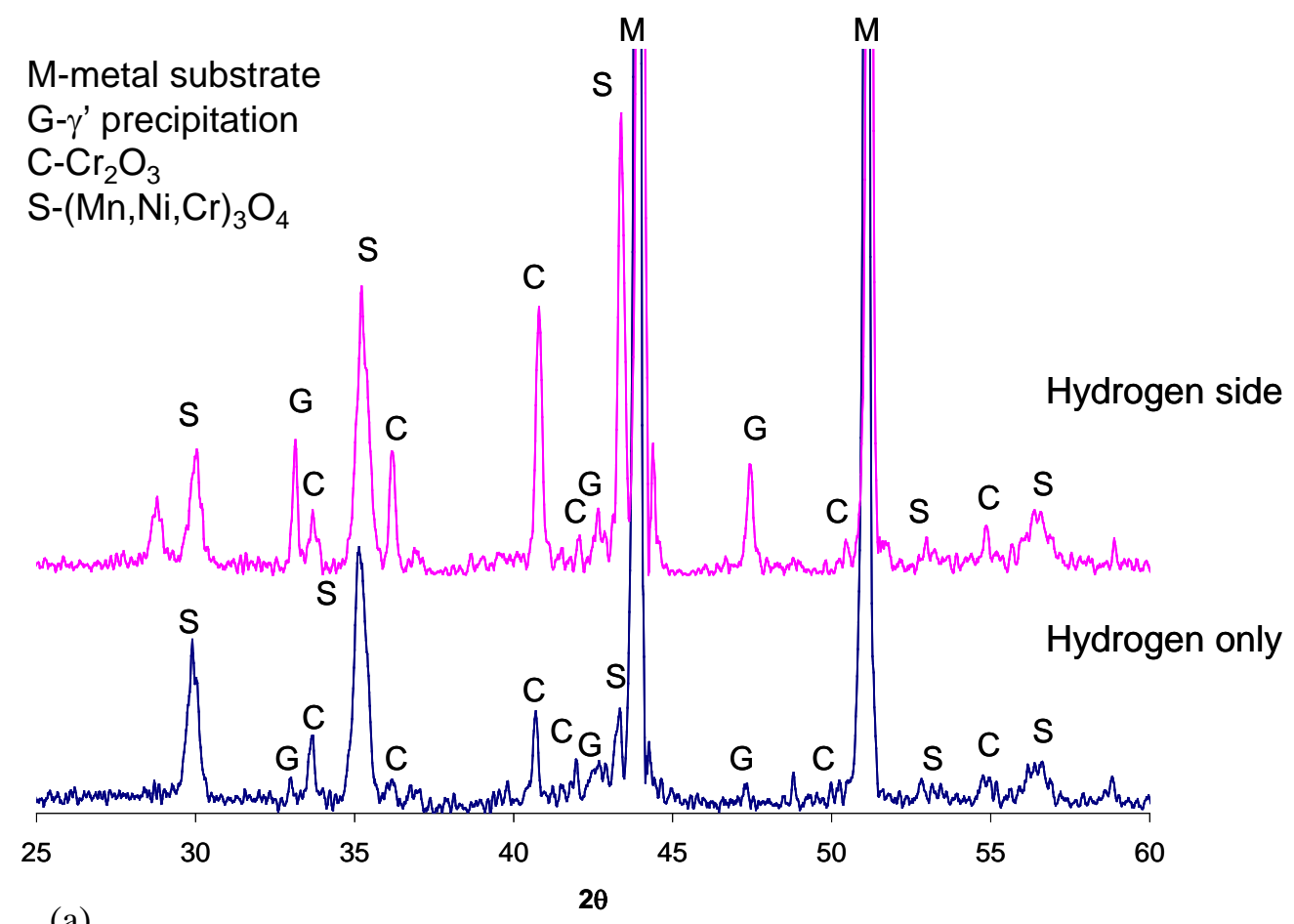

(a)

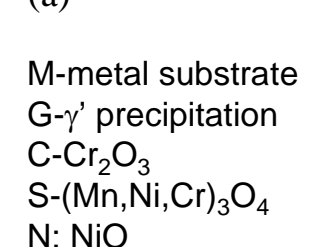

$\mathrm{N}: \mathrm{NiO}$

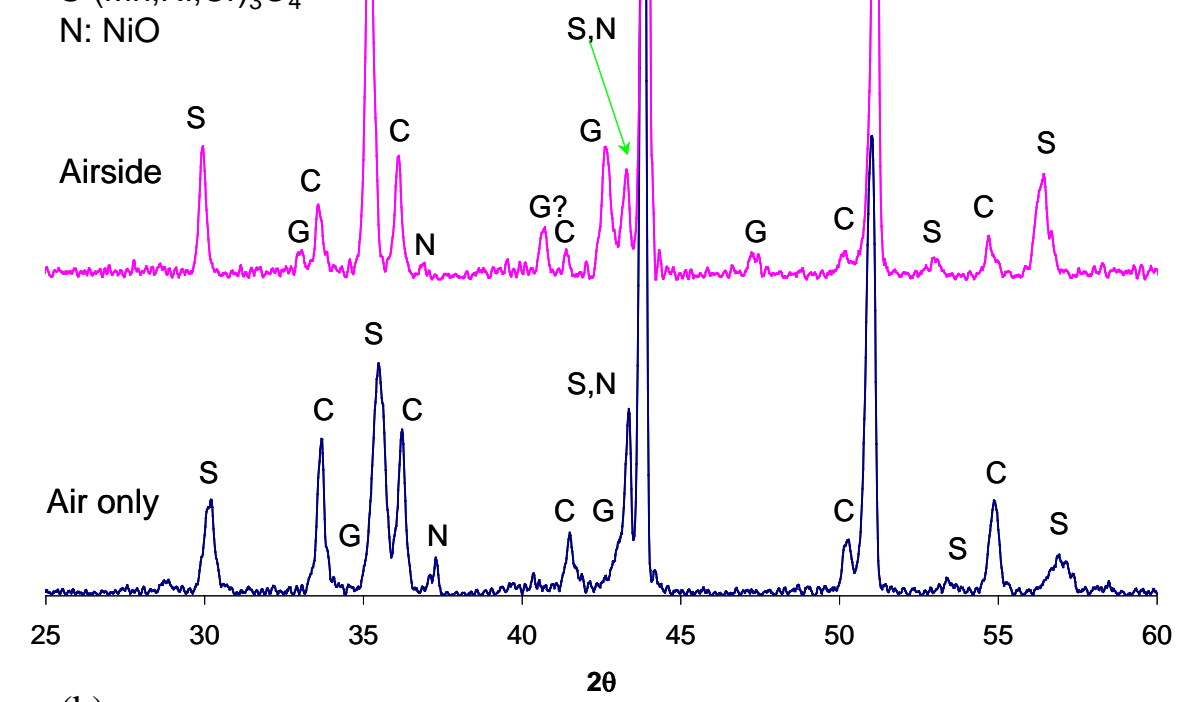

(b)

Figure 9. XRD patterns of scales grown on M2 during oxidation at $800^{\circ} \mathrm{C}$ for 300 hours: (a) at the hydrogen side of the sample that was exposed to air at the other side in comparison with that of the sample exposed to hydrogen only; (b) at the airside of the dual exposure sample in comparison with that of the sample exposed to air only. 


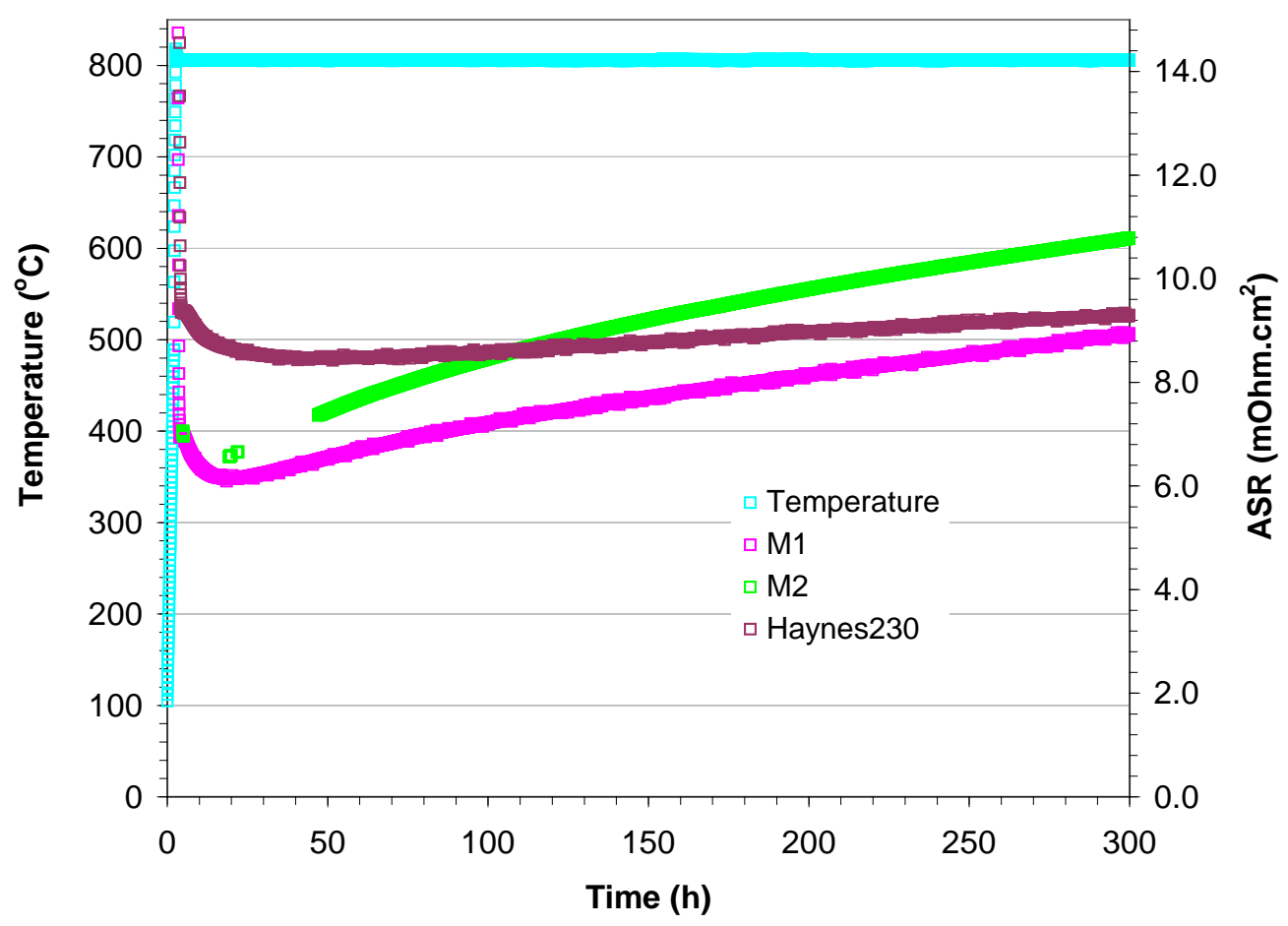

Figure 10. Area specific resistance (ASR) of the newly developed alloys as a function of time during isothermal oxidation in air at $800^{\circ} \mathrm{C}$, in comparison with that of Haynes 230 . The test coupons were pre-oxidized for 100 hours at $800^{\circ} \mathrm{C}$ in air before the ASR measurement. 


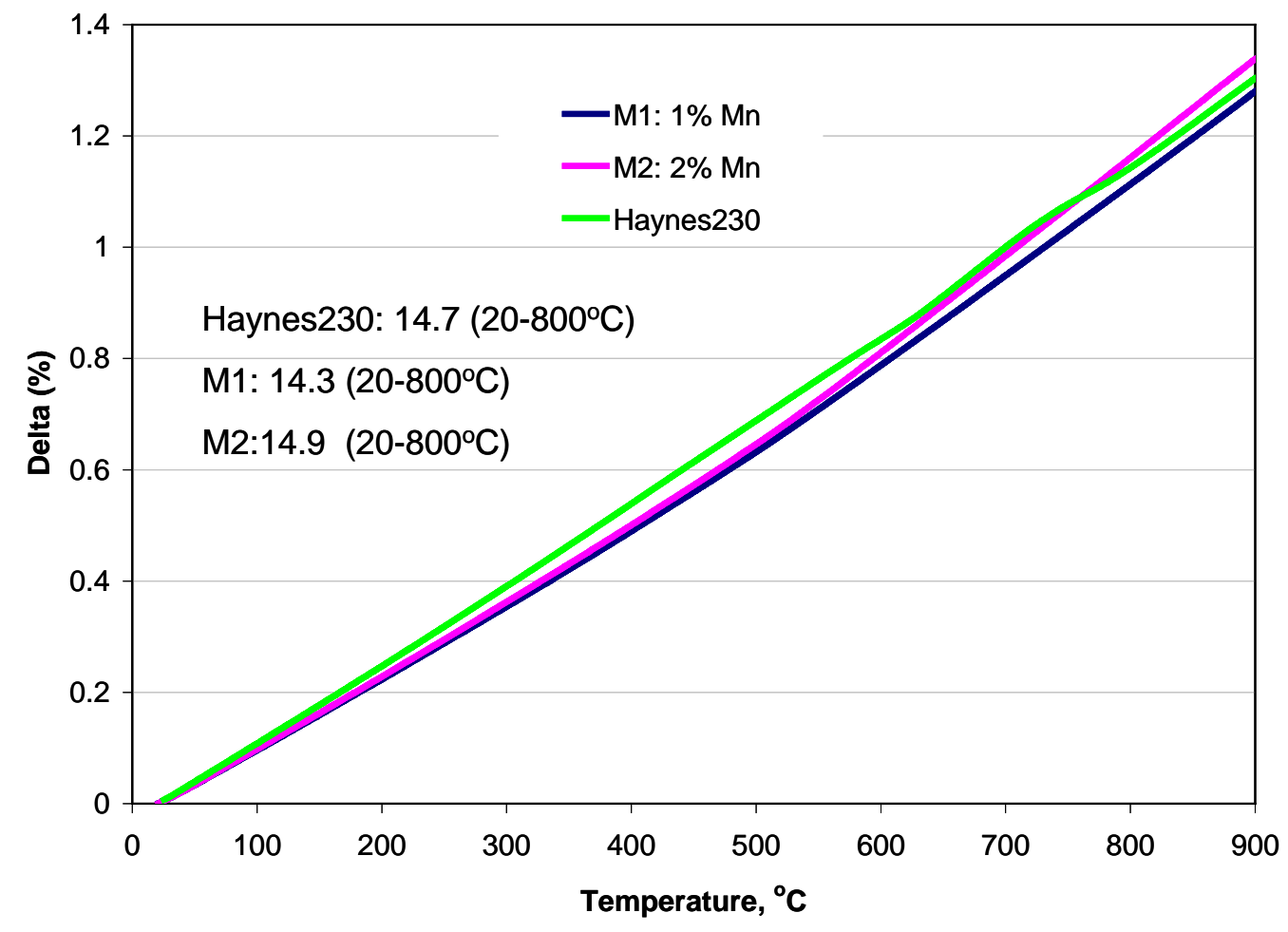

Figure 11. Thermal expansion of the newly developed Ni-Cr-W-Mn alloys, in comparison with that of Haynes 230. 


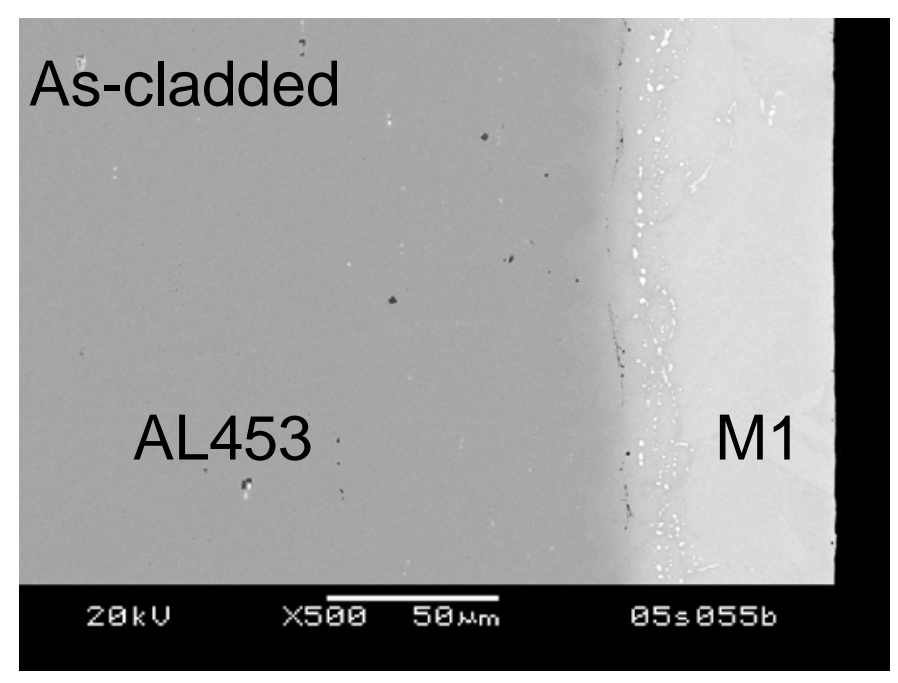

(a)

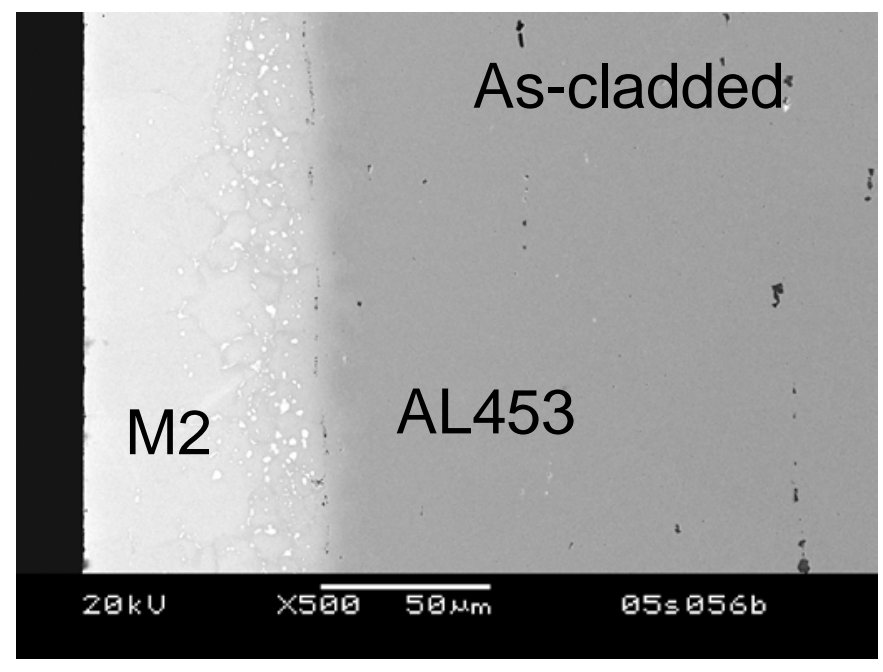

(b)

Figure 12. SEM cross-sections of a clad composite structure with Ni-Cr-W-Mn alloys as the claddings and AL453 as the substrate: (a) AL453||M1; (b) AL453||M2. 